\title{
Optimization of Fermentation Conditions for Pectin Degrading Enzyme Production by Pectinolytic Microbial Consortia Used for Jute Retting
}

\author{
Minakshi Nath, B. Majumdar", Suparna Das, Sonali P. Mazumdar, \\ A.R. Saha and S. Sarkar \\ Division of Crop Production, ICAR-Central Research Institute for Jute \& Allied Fibres, \\ Barrackpore, Kolkata, West Bengal, 700 120, India \\ *Corresponding author
}

\begin{tabular}{|c|}
\hline \\
\hline $\begin{array}{l}\text { Fermentation } \\
\text { conditions, } \\
\text { Pectinolytic microbial } \\
\text { consortia, Pectinase } \\
\text { production, Jute } \\
\text { retting. }\end{array}$ \\
\hline Article Info \\
\hline $\begin{array}{l}\text { Accepted: } \\
\text { 10 September } 2017 \\
\text { Available Online: } \\
10 \text { November } 2017\end{array}$ \\
\hline
\end{tabular}

\section{A B S T R A C T}

Three pectinolytic microbial consortia developed for faster retting of jute (Chorchorus olitorius L. and Chorchorus capsularis L.) were subjected to various $\mathrm{pH}$ (4 to 12) and media with variable nitrogen and fixed carbon sources for optimization of fermentation conditions of the consortia for cost-effective pectin degrading enzyme production. All the microbial consortia were active over a wide range of $\mathrm{pH}$ from 6 to 10 and recorded maximum polygalacturonase and pectin lyase activities at $\mathrm{pH} 10$. The polygalacturonase and pectin lyase activities of microbial consortium 3 were higher by 2.05 and 3.59 times over microbial consortium 1 and 3.66 and 4.72 times over microbial consortium 2 at $\mathrm{pH}$ 10. Among the eight media under study, the yeast extract pectin agar media recorded higher polygalacturonase and pectin lyase production by all the three pectinolytic microbial consortia. Yeast extract was found as the most suitable source of nitrogen over other source of nitrogen and suppliments for polygalacturonase and pectin lyase production. The polygalacturonase and pectin lyase production in yeast extract pectin agar media by microbial consortium 3 were higher by 2.2 and 3.3 times over microbial consortium 1 and 2.8 and 3.94 times over microbial consortium 2. Yeast extract pectin media at alkaline $\mathrm{pH}(8-10)$ recorded the maximum polygalacturonase and pectin lyase enzyme production by pectinolytic microbial consortia used for jute retting

\section{Introduction}

Jute (Corchorus olitorius $\mathrm{L}$. and C. capsularis L.), the golden fibre, is an important cash crop of Eastern India, and India earns about 2050 crores rupees annually by exporting diversified jute products. Quality jute fibre is essential for the production of diversified jute products which largely depends on the biochemical process of retting. Retting of jute is carried out by the various enzymes like polygalacturonase, pectin lyase (Soriano et al., 2005; Zhang et al., 2000), xylanase etc. secreted by the retting microbes. Uses of pectinolytic bacterial consortium for quick retting of jute have been reported by several researchers (Banik et al., 2007; Majumdar et al., 2009; Das et al., 2012; Das et al., 2015). The microbes of microbial consortium in useful association release pectinolytic enzymes (polygalacturonase, pectin lyase) and xylanase, which in turn degrade the pectin and xylan present as cementing materials. The degradation of these cementing 
materials helps in the loosening of the bondage with cellulosic fibre and easy removal of cementing portion, softening of bark tissues to obtain better quality fibre (Das et al., 2015). Higher fibre recovery and quality jute fibre production with reduction in retting duration in improved retting by using microbial consortium compared to conventional retting was reported by Das et al., (2017).

The vitality and potentiality of various pectinolytic microbes to produce enzymes intensively depends upon the selection of appropriate nutrient medium, in particular, carbon and nitrogen sources. Ammonium phosphate was found best $\mathrm{N}$ source for growth of Aspergillus niger (Joshi et al., 2006), whereas peptone, casein and ammonium sulphate were utilized well by pectinase producing fungi and maximum enzymatic activity was recorded with ammonium sulphate (Kutateladze et al., 2009). Carbon sources like polygalacturonic acid, pectin, lactose enhanced pectinase production (Kashyap and Soni, 2003) and use of $1 \%$ pectin recorded maximum PME (pectin methylesterase) (Madhania et al., 2010). Individual pectinolytic bacterial strains were found to exhibit polygalacturonase and pectin lyase activities over a wide range of $\mathrm{pH}$ (Kobayashi et al., 2001; Tamburini et al., 2003; Kashyap et al., 2000; Soriano et al., 2005).

Standardization of optimum fermentation conditions like carbon and nitrogen sources and $\mathrm{pH}$ of the growth medium is essential for cost effective production of the pectinolytic enzymes by individual or group of pectinolytic microbes. Hence, the present laboratory study was undertaken to optimize the fermentation condition of three pectinolytic microbial consortiums developed for jute retting at various co-operating centres of ICAR-Central Research Institute for Jute and Allied Fibres for cost-effective production of pectin degrading enzymes.

\section{Materials and Methods}

\section{Microbial consortium}

Three microbial consortia developed for faster retting of jute under the Technology Mission on jute project at ICAR-Central Research Institute for Jute and Allied Fibres (ICARCRIJAF), Barrackpore and its collaborating centres. The component microbes of each microbial consortium was isolated and screened out from jute retting water.

Microbial consortium 1 (MC 1) consists of 4 pectinolytic bacteria of Bacillus sp.L6, Bacillus pumilus EK 17, B. pumilus Geo-03422 and B. pumilus IK-MB12-518 F (Das et al., 2012), microbial consortium 2 (MC2) consists of three different strains of Bacillus pumilus and one strain of Bacillus subtilis (Srivastava et al., 2012) and microbial consortium 3 (MC 3) consists of Bacillus pumilus IMAU80221, B. pumilus GVC11 and B. pumilus SYBC-W (Majumdar et al., 2009; Das et al., 2015). The microbes of MC1 \& MC2 have cellulolytic activities whereas; the microbes of MC3 do not have any cellulolytic activities. The pure cultures of microbial consortiums were used for the study.

\section{pH optimization}

For $\mathrm{pH}$ optimization, nine different buffers of $\mathrm{pH}$ values ranging from 4 to 12 were used respectively as potassium hydrogen phthalate$\mathrm{NaOH}$ buffer ( $\mathrm{pH} 4.0$ ), Potassium hydrogen phthalate- $\mathrm{NaOH}$ buffer ( $\mathrm{pH}$ 5.0), Potassium di-hydrogen phosphate $\left(\mathrm{KH}_{2} \mathrm{PO}_{4}\right)-\mathrm{NaOH}$ buffer ( $\mathrm{pH}$ 6.0), Tris-HCl buffer ( $\mathrm{pH} 7.0$ ), Tris-HCl buffer ( $\mathrm{pH} 8.0$ ), Tris- $\mathrm{HCl}$ buffer (pH 9.0), Borax-NaOH buffer (pH 10.0), Sodium-bicarbonate $\left(\mathrm{NaHCO}_{3}\right)-\mathrm{NaOH}$ buffer (pH 11.0), Potassium chloride (KCl)-NaOH 
buffer ( $\mathrm{pH}$ 12.0). Pure cultures of each of the component microorganisms of the microbial consortium were streaked on pectin agar plate and incubated for $48 \mathrm{hrs}$, and then a single colony of the isolates were inoculated in 10 $\mathrm{ml}$ pectin broth and incubated at $34^{\circ} \mathrm{C}$ at 180 rpm for $24 \mathrm{hrs}$ to synchronize the growth of individual culture. After $24 \mathrm{hrs}$ of incubation, each consortium was inoculated @ 1\% in 100 $\mathrm{ml}$ pectin broth $(1 \%$ pectin $+1 \%$ yeast extract $+0.5 \% \mathrm{NaCl}$ ) and incubated at $180 \mathrm{rpm}$ for $48 \mathrm{hrs}$ and the supernatant obtained after centrifugation at $10000 \mathrm{rpm}$ for 10 minutes were used for polygalacturonase and pectin lyase assay. Polygalacturonase (PG) enzyme assay was done by DNS method of Miller, (1959), later modified by Phutela et al., (2005). One unit (IU) of polygalacturonase activity corresponds to the release of $1 \mu \mathrm{mol}$ of galacturonic acid $/ \mathrm{min} / \mathrm{ml}$ of supernatant culture keeping D-galacturonic acid as the calibration standard. Pectin lyase (PNL) enzyme assay was done by following the modified TBA method of Nedjma et al., (2001). One unit (U) of pectin lyase activity defined as the amount of enzyme that caused a change in absorbance of 0.01 under the assay condition. On the basis of maximum PG and PNL activities, the $\mathrm{pH}$ value was optimized for each consortium.

\section{Media optimization}

After determination of optimum $\mathrm{pH}$, each consortium was tested at its individual optimum $\mathrm{pH}$ value for production of highest amount of polygalacturonase and pectin lyase enzyme activities using 8 different media having fixed carbon source and variable nitrogen source or supplements. On the basis of maximum PG and PNL enzyme activities, best suitable media was standardized for three different consortiums. Seven media used were respectively as Media $1-(1 \%$ pectin $+1 \%$ yeast extract $+0.5 \% \mathrm{NaCl})$, Media $2-(0.5 \%$ glucose $+1 \%$ pectin $+1 \%$ yeast extract + $0.5 \% \mathrm{NaCl})$, Media 3- $\left(0.5 \% \mathrm{CaCl}_{2}+1 \%\right.$ pectin $+1 \%$ yeast extract $+0.5 \% \mathrm{NaCl}$ ), Media 4- $(1 \%$ pectin $+0.5 \%$ ammonium sulphate $+0.5 \% \mathrm{NaCl})$, Media $5-(1 \%$ pectin $+0.5 \%$ ammonium oxalate $+0.5 \% \mathrm{NaCl}$ ), Media 6- $(1.5 \%$ pectin $+0.5 \%$ ammonium nitrate $+0.5 \% \mathrm{NaCl})$, Media $7-(1 \%$ pectin + $0.5 \%$ peptone $+0.5 \% \mathrm{NaCl})$ and Media 8$(1 \%$ pectin $+0.5 \%$ beef extract $+0.5 \% \mathrm{NaCl})$. In media 2 and 3 , glucose and $\mathrm{CaCl}_{2}$ were added as supplements to the yeast extract pectin medium. In medium 4,5 and 6 , ammonium sulphate, ammonium oxalate and ammonium nitrate were respectively used as the sole source of nitrogen instead of yeast extract. In medium 7 and 8, yeast extract as nitrogen source was replaced respectively by peptone and beef extract. Each consortium was inoculated @ 1\% in 100 ml broth of eight media under study and incubated at $180 \mathrm{rpm}$ for $48 \mathrm{hrs}$ and the supernatant obtained after centrifugation at $10000 \mathrm{rpm}$ for 10 minutes were used for polygalacturonase and pectin lyase assay as described earlier.

\section{Statistical analysis}

The data were analysed as a single factor one way analyses of variance (ANOVA) in a completely randomized block design using SPSS 10.0 for windows (SPSS Inc., USA). Means were separated by using Duncan's multiple range test (DMRT) at 5\% probability level of statistical significance.

\section{Results and Discussion}

\section{Effect of pH on PG and PNL activities}

The effect of wide range of $\mathrm{pH}$ (4 to 12) was tested on the polygalacturonase (PG) and pectin lyase (PNL) activities of three microbial retting consortiums (Table 1). The microbial consortium 1 (MC1) recorded a peak of $\mathrm{PG}$ activity at $\mathrm{pH} 6.0$ and thereafter 
more than two fold increase in PG activity at $\mathrm{pH} 8.0(10.7 \mathrm{IU} / \mathrm{ml})$, which was at par with the recorded activities at $\mathrm{pH} 9.0(10.4 \mathrm{IU} / \mathrm{ml})$ and $10.0(10.8 \mathrm{IU} / \mathrm{ml})$ which then decreased significantly with increase in $\mathrm{pH}$. The microbial consortium 2 (MC2) recorded a gradual increase in $\mathrm{PG}$ activity with increase in $\mathrm{pH}$ up to 10.0 and thereafter reduced with increase in $\mathrm{pH}$. The maximum $\mathrm{PG}$ activity (7.5 IU/ml) by MC2 was recorded at $\mathrm{pH} 10.0$ followed by activities of 5.43 and $5.3 \mathrm{IU} / \mathrm{ml}$ respectively at $\mathrm{pH} 9.0$ and 11.0 .

The microbial consortium 3 (MC3) recorded a significantly higher PG value at $\mathrm{pH} 6.0$ (9.35 $\mathrm{IU} / \mathrm{ml}$ ) and thereafter two significant peaks of $\mathrm{PG}$ activities at $\mathrm{pH} 9.0(11.75 \mathrm{IU} / \mathrm{ml})$ and 10.0 (20.2 IU/ml), thereafter reduced significantly at $\mathrm{pH} 11.0(10.1 \mathrm{IU} / \mathrm{ml})$. Although, the three microbial retting consortiums recorded maximum PG activity at $\mathrm{pH} 10.0$, but the PG activity of MC3 was higher by 2.05 and 3.66 times over $\mathrm{MC} 1$ and $\mathrm{MC} 2$ at their respective $\mathrm{pH}$. The retting consortiums were very active over a wide range of $\mathrm{pH}$ from 6.0 to 10.0 with higher $\mathrm{PG}$ activities in the alkaline range.

The pectin lyase activity was very low at $\mathrm{pH}$ 4.0 and 5.0 by $\mathrm{MC} 1$ and $\mathrm{MC} 2$, then sudden increase in PNL activity at $\mathrm{pH} 6.0$ onwards and the maximum PNL activity was recorded at $\mathrm{pH} 10.0$ by $\mathrm{MC} 1(50.2 \mathrm{U} / \mathrm{ml})$ and $\mathrm{MC} 2$ (38.2 U/ml). Unlike the MC1 and MC2, the MC3 recorded very high PNL activities starting from $\mathrm{pH} 4.0$ and there was significant increase in PNL activity with increase in $\mathrm{pH}$ up to 10.0 and the maximum PNL activity (180.5 U/ml) was recorded at $\mathrm{pH} 10.0$ which was higher by 3.59 and 4.72 times over $\mathrm{MC} 1$ and MC2 at the same $\mathrm{pH}$. The PNL activity of MC3 was higher by several times at each $\mathrm{pH}$ value under study over MC1 and MC2. From the PG and PNL activities over a wide range of $\mathrm{pH}$ values, it is clear that MC3 was better among the three retting consortium under study as it recorded higher PG and PNL activities over MC1 and MC2.

Individual pectinolytic bacterial isolates showed higher PG and PNL activities in between $\mathrm{pH} 8.0$ and 8.5 as reported by Kashyap et al., (2000); Tamburini et al., (2003); Das et al., (2011). On the other hand, Soriano et al., (2005) reported higher PNL activities by Paenibacillus sp, BP-23 \& BP-7 at $\mathrm{pH}$ 10.0. In the present study, PG and PNL activities of three retting consortium consisting of more than two pectinolytic bacterial isolates were studied in a wide range of $\mathrm{pH}$ from 4 to 12.0 .

Table.1 Effect of $\mathrm{pH}$ on polygalacturonase and pectin lyase activities of microbial consortia

\begin{tabular}{|l|c|c|c|c|c|c|}
\hline \multirow{2}{*}{ pH values } & \multicolumn{2}{|c|}{ Polygalacturonase activity (IU/ml) } & \multicolumn{3}{c|}{ Pectin lyase activity (U/ml) } \\
\cline { 2 - 7 } & MC1 & MC2 & MC3 & MC1 & MC2 & MC3 \\
\hline 4.0 & $0.70^{\mathrm{f}}$ & $1.16^{\mathrm{g}}$ & $4.00^{\mathrm{f}}$ & $2.00^{\mathrm{f}}$ & $1.00^{\mathrm{h}}$ & $8.20^{\mathrm{h}}$ \\
\hline 5.0 & $2.52^{\mathrm{e}}$ & $2.22^{\mathrm{f}}$ & $7.59^{\mathrm{e}}$ & $3.70^{\mathrm{f}}$ & $1.60^{\mathrm{h}}$ & $16.50^{\mathrm{g}}$ \\
\hline 6.0 & $4.56^{\mathrm{c}}$ & $2.55^{\mathrm{e}}$ & $9.35^{\mathrm{cd}}$ & $10.00^{\mathrm{e}}$ & $7.80^{\mathrm{g}}$ & $25.20^{\mathrm{f}}$ \\
\hline 7.0 & $2.93^{\mathrm{e}}$ & $3.21^{\mathrm{d}}$ & $7.40^{\mathrm{e}}$ & $11.50^{\mathrm{e}}$ & $12.50^{\mathrm{f}}$ & $40.20^{\mathrm{e}}$ \\
\hline 8.0 & $10.70^{\mathrm{a}}$ & $3.95^{\mathrm{c}}$ & $8.66^{\mathrm{d}}$ & $48.50^{\mathrm{ab}}$ & $20.20^{\mathrm{d}}$ & $69.50^{\mathrm{d}}$ \\
\hline 9.0 & $10.40^{\mathrm{a}}$ & $5.43^{\mathrm{b}}$ & $11.75^{\mathrm{b}}$ & $46.40^{\mathrm{b}}$ & $26.80^{\mathrm{c}}$ & $120.60^{\mathrm{b}}$ \\
\hline 10.0 & $10.80^{\mathrm{a}}$ & $7.50^{\mathrm{a}}$ & $20.20^{\mathrm{a}}$ & $50.20^{\mathrm{a}}$ & $38.20^{\mathrm{a}}$ & $180.50^{\mathrm{a}}$ \\
\hline 11.0 & $6.26^{\mathrm{b}}$ & $5.30^{\mathrm{b}}$ & $10.10^{\mathrm{c}}$ & $27.50^{\mathrm{c}}$ & $32.00^{\mathrm{b}}$ & $120.20^{\mathrm{b}}$ \\
\hline 12.0 & $3.82^{\mathrm{d}}$ & $2.61^{\mathrm{e}}$ & $9.80^{\mathrm{c}}$ & $16.50^{\mathrm{d}}$ & $15.20^{\mathrm{e}}$ & $95.50^{\mathrm{c}}$ \\
\hline
\end{tabular}

Means with common letters at the superscript in a column are not statistically different at $5 \%$ probability level by DMRT 
Table.2 Effect of different media on polygalacturonase and pectin lyase activities of microbial consortia

\begin{tabular}{|l|c|c|c|c|c|c|}
\hline \multirow{2}{*}{ Media } & \multicolumn{2}{|c|}{ Polygalacturonase activity (IU/mI) } & \multicolumn{2}{c|}{ Pectin lyase activity (U/ml) } \\
\cline { 2 - 7 } & MC1 & MC2 & MC3 & MC1 & MC2 & MC3 \\
\hline Media 1 & $8.50^{\mathrm{a}}$ & $6.50^{\mathrm{a}}$ & $18.50^{\mathrm{a}}$ & $60.50^{\mathrm{a}}$ & $50.80^{\mathrm{a}}$ & $200.00^{\mathrm{a}}$ \\
\hline Media 2 & $6.90^{\mathrm{b}}$ & $3.28^{\mathrm{b}}$ & $1.03^{\mathrm{d}}$ & $46.20^{\mathrm{b}}$ & $38.20^{\mathrm{b}}$ & $40.20^{\mathrm{d}}$ \\
\hline Media 3 & $1.43^{\mathrm{f}}$ & $1.12^{\mathrm{e}}$ & $0.85^{\mathrm{d}}$ & $15.40^{\mathrm{f}}$ & $21.40^{\mathrm{e}}$ & $34.20^{\mathrm{e}}$ \\
\hline Media 4 & $4.05^{\mathrm{c}}$ & $1.84^{\mathrm{d}}$ & $3.20^{\mathrm{c}}$ & $38.50^{\mathrm{c}}$ & $26.20^{\mathrm{d}}$ & $45.50^{\mathrm{c}}$ \\
\hline Media 5 & $0.90^{\mathrm{g}}$ & $0.93^{\mathrm{e}}$ & $4.62^{\mathrm{b}}$ & $10.20^{\mathrm{g}}$ & $16.60^{\mathrm{f}}$ & $56.20^{\mathrm{b}}$ \\
\hline Media 6 & $3.77^{\mathrm{c}}$ & $2.33^{\mathrm{c}}$ & $0.54^{\mathrm{de}}$ & $36.80^{\mathrm{c}}$ & $30.50^{\mathrm{c}}$ & $30.50^{\mathrm{f}}$ \\
\hline Media 7 & $2.54^{\mathrm{e}}$ & $0.24^{\mathrm{f}}$ & $0.45^{\mathrm{e}}$ & $22.60^{\mathrm{e}}$ & $11.20^{\mathrm{g}}$ & $31.20^{\mathrm{f}}$ \\
\hline Media 8 & $3.42^{\mathrm{d}}$ & $0.96^{\mathrm{e}}$ & $4.33^{\mathrm{b}}$ & $30.20^{\mathrm{d}}$ & $20.50^{\mathrm{e}}$ & $58.80^{\mathrm{b}}$ \\
\hline
\end{tabular}

Means with common letters at the superscript in a column are not statistically different at $5 \%$ probability level by DMRT

All the three retting consortium were found to active for PG \& PNL activities over a wide range of $\mathrm{pH}$ from 6 to 10.0 with maximum values at $\mathrm{pH} 10.0$, while in case of individual microbes, the maximum $\mathrm{PG}$ and PNL activities were recorded at $\mathrm{pH}$ between 8 and 8.5 as reported by earlier researchers. As there is no report of $\mathrm{PG}$ and PNL activities of microbial consortium at different $\mathrm{pH}$, the result could not be compared.

\section{Effect of media on PG and PNL activities}

The maximum polygalacturonase (PG) activity was observed by three microbial consortiums in yeast extract pectin (YEP) medium (Table 2). The next higher values of PG activity was recorded in medium 2 (glucose + YEP) by MC1 and MC2, whereas, MC3 recorded higher PG activity in ammonium oxalate, beef extract and ammonium sulphate after YEP medium. Addition of glucose and $\mathrm{CaCl}_{2}$ as supplements to YEP medium decreased the PG activity by MC3. The microbes of MC3 are non-cellulolytic in nature, so addition of cellulose might have affected their growth and reduced the PG activity. Among the three consortiums, MC3 recorded very high PG activity $(18.5 \mathrm{IU} / \mathrm{ml})$ in YEP medium compared to other two microbial consortiums and it was higher by 2.2 and 2.8 times over respective $\mathrm{PG}$ activity of $\mathrm{MC} 1$ and $\mathrm{MC} 2$. The results are in agreement with others where they have reported the combination of yeast extract with pectin to be the best medium for polygalacturonase production (Kashyap et al., 2000; Muslim et al., 2015). The MC1 and MC2 also recorded higher values of PG activity in ammonium sulphate and ammonium nitrate. Beef extract was found as a good source of nitrogen for PG production by MC3, but among inorganic sources of $\mathrm{N}$, ammonium sulphate was a good source of nitrogen as also reported by Muslim et al., (2015).

The pectin lyase activity of three microbial consortiums was also affected by various source of nitrogen in the medium (Table 2). The highest pectin lyase activity was recorded by the entire microbial consortium with yeast extract; MC3 recorded pectin lyase activity of $200 \mathrm{U} / \mathrm{ml}$ which was higher by 3.3 and 3.94 times respectively over $\mathrm{MC} 1$ and $\mathrm{MC} 2$. The microbial consortium MC1 and MC2 recorded next higher pectin lyase activity with yeast extract and glucose as supplement followed by ammonium sulphate in case of $\mathrm{MC} 1$ and ammonium nitrate in case of MC2. 
On the other hand, MC3 recorded next higher values of pectin lyase activity $(80.8 \mathrm{U} / \mathrm{ml})$ with beef extract and ammonium oxalate $(56.2 \mathrm{U} / \mathrm{ml})$ as $\mathrm{N}$ source. Yeast extract was found the best nitrogen source for PG and PNL production probably due to its higher content of minerals, vitamins, coenzyme and nitrogen components (McMillan and Johnson, 2005) for the three microbial consortia.

It can be concluded from the study that by using yeast extract pectin media at alkaine $\mathrm{pH}$ (8-10), maximum polygalacturonase and pectin lyase enzyme production by pectinolytic microbial consortia can be achieved. Among the three microbial consortia under study, the polygalacturonase and pectin lyase production in yeast extract pectin agar media by microbial consortium 3 were significantly higher over microbial consortium 1 and 2.

\section{References}

Banik, S., Basak, M.K., Paul, D., Nayak, P., Sardar, D., Sil, S.C., Sanpui, B.C. and Ghosh, A. 2003. Effect of inoculation of pectinolytic mixed bacterial culture on improvement of ribbon retting of jute and kenaf. J. Nat. Fibers 4: 33-50.

Das, B., Chakrabarti, K., Ghosh, S., Majumdar, B., Tripathi, S. and Chakraborty, A. 2012. Effect of efficient pectinolytic bacterial isolates on retting and fibre quality of jute. Ind. Crops Prod. 36: 415-419.

Das, B., Chakraborty, A., Ghosh, S. and Chakrabarti, K. 2011. Studies on the effect of $\mathrm{pH}$ and carbon sources on enzyme activities of some pectinolytic bacteria isolated from jute retting water. Turk. J. Biol. 35(1):1-8.

Das, Suparna, Majumdar, B. and Saha, A.R. 2015. Biodegradation of plant pectin and hemicelluloses with three novel Bacillus pumilus strains and their combined application for quality jute fibre production. Agric. Res. 4(4): 354364.

Das, Suparna, Majumdar, B., Saha, A. R., Sarkar, S., Jha, S. K., Sarkar, S. K., Saha, R. (2017). Comparative Study of Conventional and Improved Retting of Jute with Microbial Formulation. Proc. Natl. Acad. Sci., India, Sect. B Biol. Sci. DOI 10.1007/s40011-017-0872-x.

Joshi, V.K., Parmar, M. and Rana, N.S. 2006. Pectinesterase production from apple pomace in solid state and submerged fermentations. Food Technology and Biotechnology 44: 253-256.

Kashyap, D.R., Chandra, S., Kaul, A. and Tewari, R. 2000. Production, purification and characterization of pectinase from a Bacillus sp. DT7. World J. Microbiol. Biotecnol. 16(3): 277-282.

Kashyap, R., Soni, S. K. and Tewari, R. 2003. Enhanced production of pectinase by Bacillus sp. DT7 using solid-state fermentation. Bioresouce Technol. 88(3): 251-254.

Kobayashi, T., Higaki, N., Suzumatsu, A., Sawada, K., Hagihara, H., Kawai, S. and Ito, S. 2001. Purification and properties of a high-molecular-weight, alkaline exopolygalacturonase from a strain of Bacillus. Enzyme and Microbial Technology 29(1): 70-75.

Kutateladze, L., Zakariashvili, N., Jobava, M., Urushadze, T., Khvedelidze, R. and Khokhashvili, I. 2009. Selection of microscopic fungi-pectinase producers. Bulletin of the Georgian National Academy of Sciences 3(1): 136-141.

Madhania, S., Jain, V. and Malhotra, S.P. 2010. Culture optimization for enhanced production of microbial pectin methyl esterase under submerged conditions. Asian J. Biochem. 5(1): 1222.

Majumdar, B., Das, S., Saha, A.R., Maitra, 
D.N. and Chowdhury, H. 2009. Development and use of promising microbial consortium for jute retting. Jaf News 7(1): 14-15.

McMillan, G.P. and Johnson, D.J. 2005. Purification and characterization of a high pectin methylesterase isozyme and its inhibitor from tubes of Solanum tuberosum. Physiological and Molecular Plant Pathology 46: 413 427.

Muslim, S.N., Al_Kadmy, I.M.S., Mahammed, A.N., Musafer, H.K. and Muslim, S.N. 2015. Detection of the optimal conditions for pectate lyase productivity and activity by Erwinia chrysanthemi. J. Medical and Bioengineering, 4(3): 184-191.

Nedjma, M., Hoffmann, N. and Belarbi, A. 2001. Selective and sensitive detection of pectin lyase activity using a colorimetric test: application to the screening of microorganisms possessing pectin lyase activity. Anal. Biochem. 291: 290-296.

Phutela, U., Dhuna, V., Sandhu, S. and
Chadha, B.S. 2005. Pectinase and polygalacturonase production by a thermophilic Aspergillus fumigatus isolated from decomposing orange peels. Braz. J. Microbiol. 36:63-69.

Soriano, M., Diaz, P. and Pastor, F.I.J. 2005. Pectinolytic systems of two aerobic sporogenous bacterial strains with high activity on pectin. Curr. Microbiol. 50: 114-118.

Srivastava, R.K., Kumar, N., Singh, R.K., Majumdar, B., Mahapatra, B.S., Katiyar, T.P.S. and Kureel, R.S. 2012. Improvement of fibre quality through microbial retting in jute. Research Bulletin, N.D.UA\&T, CRS, Bahraich. pp.31.

Tamburini, E., Leon, A.G., Pertio, B., and Mastromei, G. 2003. Characterization of bacterial pectinolytic strains involved in the water retting process. Environ. Microbiol. 5(9): 730-736.

Zhang, J., Henriksson, G., Johansson, G. 2000. Polygalacturonase is the key component in enzymatic retting of flax. J. Biotechnol. 81: 85-89.

\section{How to cite this article:}

Minakshi Nath, B. Majumdar, Suparna Das, Sonali P. Mazumdar, A.R. Saha and Sarkar, S. 2017. Optimization of Fermentation Conditions for Pectin Degrading Enzyme Production by Pectinolytic Microbial Consortia Used for Jute Retting. Int.J.Curr.Microbiol.App.Sci. 6(11): 925-931. doi: https://doi.org/10.20546/ijcmas.2017.611.108 